\title{
COMMENTS
}

\section{The Council of Revision and the Limits of Judicial Power}

\author{
James T. Barry III†
}

The limits of judicial power and the proper role of the judiciary in the Constitutional scheme have always been matters of great controversy. Recent manifestations of this controversy include the debate over the scope of the Fourteenth Amendment, the breadth of standing requirements, the inclusion of judges on the Federal Sentencing Commission, and the role of the judiciary in appointing independent counsels to investigate executive branch officials. Although these issues are usually discussed on more abstract grounds, the historical background of the Constitution often creeps into the debate.

In this context, one event often mentioned is the Framers' debate over and rejection of a Council of Revision at the Constitutional Convention of 1787. The proposed Council would have vested the federal veto power in an institution composed of the President and several members of the federal judiciary, presumably the Justices of the Supreme Court. The history of this proposal illustrates how the Framers, faced with a model of judicial involvement in the lawmaking process, chose instead a judiciary that took no part in the creation of laws. In so doing, the Framers effectively chose to preclude the courts from deciding matters of public policy and to create a special place for the courts in the separation of powers scheme.

Though the history of the proposed Council is relevant to many issues that perennially confront the courts, scholars have given that history remarkably little attention. This comment seeks to remedy that lack of scholarship by examining the history of the

† B.S.F.S., Georgetown University, 1986; J.D. Candidate, University of Chicago, 1989. 
Council of Revision and the reasons for its rejection. Section I of the comment examines the historical and theoretical roots of the Council of Revision, particularly its antecedents in English institutions and in political theory that was popular at the time of the Convention. This section will attempt to place the proposal for a Council of Revision in its proper historical and theoretical context. Section II discusses a more tangible influence on the Framers' debate over the Council of Revision-the New York Council of Revision, which not only laid the blueprint for the proposed national Council but also vividly illustrated the strengths and weaknesses of such a proposal.

Section III discusses the proposal of, debate over, and rejection of the Council of Revision at the Constitutional Convention of 1787. This section will analyze the arguments offered for and against the Council of Revision and discuss the historical conclusions that can be validly drawn from the Council's rejection. The comment will conclude with some observations on the current relevance of the history of the Council of Revision to the modern role of judges and the judiciary.

The Framers considered a host of well-articulated arguments both for and against the Council of Revision and soundly defeated the proposal on three separate occasions. In rejecting the Council, the Framers also rejected an entrenched tradition of the role of courts and judges in government, adopting instead a relatively novel theory of that role. Moreover, the Framers' rejection of the Council of Revision represented one of the rare victories for the proponents of a "pure" separation of powers system. The proponents of a flexible separation of powers system succeeded in mixing the powers of the branches in the context of the executive veto, the impeachment power, the appointment power and other functions, but failed to convince other delegates that the judiciary should share in the lawmaking power.

The Framers decided the issues raised in the Council of Revision debate with an authority and certainty that is often lacking in the current debate over the proper role of the courts. The rejection of the Council of Revision thus provides a significant guidepost for resolving current controversies regarding the role of the courts in the separation of powers system and the role of judges in the lawmaking process. Indeed, the history of the proposed Council of Revision illustrates the validity of Justice Holmes's famous maxim: "a 
page of history is worth a volume of logic."1

I. The Historical Origins of the Proposal for a National CouncIL of Revision

A. English Precedent

The idea of a council with broad authority over the activities of the government has its roots in primitive legal customs. Sir Henry Sumner Maine observed that ancient societies gradually moved from monarchic to oligarchic structures. In other words, "the office of the king was usurped by [the] council of chiefs. ..." The early history of English government reflects this trend.

The Anglo-Saxon kings of pre-Norman England retained a council of advisers known as the witan. The king shared his inherent power to declare the law with this group. As Stanley Chrimes explained:

The old English king was not the source of law, even though it was his duty to enforce it as far as he could-which was often not very far. Law was tribal custom, or folkright, to which the king was subordinate in every respect, as any other member of the folk. He might, and on occasion did, find it necessary to declare, with the express or tacit assent of the 'wise men' of his realm (the witan), what the law was on certain points, and even to commit such declarations to writing. ${ }^{3}$

After the Norman conquest, the witan, along with the king's tenants-in-chief and household administrators, became known as the Curia Regis, or the King's Court. ${ }^{4}$ Early on, the King's Court itself exercised judicial, legislative, and executive functions. Gradually, however, the common law courts and an executive council emerged from the King's Court and began to perform specialized functions. Nevertheless, "[t]he courts did a certain amount of administrative work, and the Council had a large share in judicature as well as legislation."'

${ }^{1}$ New York Trust Co. $v$ Eisner, 256 US 345, 349 (1921).

${ }^{2}$ Henry Sumner Maine, Ancient Law 9 (Henry Holt, 1874). For a more complete discussion of the role played by councils in primitive legal systems, see Robert H. Lowie, Primitive Society 358-89 (1920).

3 Stanley B. Chrimes, English Constitutional History 53-54 (Oxford, 4th ed 1967). See also William Holdsworth, 1 A History of English Law 15-16 (Meuthen, 7th ed 1956).

- Chrimes, English Constitutional History at 64-66 (cited in note 3). According to Holdsworth, "[t] he Curia Regis was a legislative, an administrative, and a judicial body." Holdsworth, History of English Law at 39 (cited in note 3).

- Theodore F.T. Plucknett, A Concise History of the Common Law 146 (Butterworth, 
By the reign of Henry VII, the King's Council, or Privy Council, had become the sovereign's principal tool for enforcing absolute rule through both executive and judicial means. Henry VII replaced the independent but inactive members of the Council with "ruthless administrators ... who could be trusted to put the king's business before all else, and steadfastly to carry out the king's will." At the same time that Henry VII was strengthening the Council's executive powers, Parliament sought to expand the Council's judicial powers through legislation such as the "Star Chamber" Act of 1487, which created a special court of general jurisdiction within the Council." Through the efforts of several monarchs, the Tudor Privy Council, armed with extensive and overlapping executive and judicial powers, became a "tremendously energetic instrument of the royal will."

The Stuart monarchs attempted to sustain the Privy Council as an organ of absolute rule by using the Council's judicial components to implement state policy directly. For example, the Stuarts transformed the Council's court of Star Chamber from a relatively benign court of criminal equity into a vigorous and increasingly unpopular enforcer of state proclamations. ${ }^{9}$ In the midst of the English Civil War, the Long Parliament, reacting to the excesses of monarchical despotism, abolished all the judicial functions of the various Councils. ${ }^{10}$ Thereafter, only a weakened Privy Council, stripped of most of its real power, remained.

With the expansion of the British Empire, however, the administrative and judicial powers of the Privy Council were revived. The Act of 1640 had only abolished the Council's judicial authority within England; in the imperial territories, the Council retained its dual role as both the dispenser of the sovereign's justice and as the final body of approval for legislation. ${ }^{11}$ Throughout the Empire, the Council exercised final say over colonial laws and served as the ultimate court of appeal in colonial cases. A committee of the Council, called the Lords Committee, handled most of these matters. ${ }^{12}$ Through the Lords Committee, the Privy Council could re-

5th ed 1956). For a detailed overview of the evolution of the judicial system in England, see id at $142-156$.

- Chrimes, English Constitutional History at 90 (cited in note 3).

Id at 91.

Id at 91 .

Id at 108, 111.

${ }^{10}$ Statute 16 Chas I, c 10 (1640).

1 See Holdsworth, History of English Law at 479 (cited in note 3).

12 Julius J. Goebel, Jr., 1 History of the Supreme Court of the United States 65-69 
view colonial legislation "both in the process of administrative review, and judicially, upon appeal."13 As John P. Frank explained:

The most significant aspect of Privy Council review of colonial legal problems is that, by virtue of the Council's double jurisdiction, it merged into one body the systems of both legislative and judicial review. It could disapprove of statutes by veto and could also invalidate a colonial statute in the course of deciding a case. ${ }^{14}$

The English Privy Council and particularly the operations of the Lords Committee vividly illustrate England's strong tradition of judicial involvement in legislative and executive functions.

In England, there seemed to be no question as to the propriety of high judicial officials exercising non-judicial power. The Lord Chancellor, for example, served simultaneously as a judge, the head of the Chancery courts, a close adviser to the King, a cabinet member, and President of the House of Lords. As Holdsworth put it, the Chancellor, who was by name a judicial officer, was also in "direct connexion with all the parts of the constitution."15

The function of the English House of Lords also illustrates the ambivalence of the English towards the notion that judicial power be strictly separated from the other branches. The House of Lords functioned as both a legislative and a judicial body. At the time of the American Constitutional Convention, it constituted both the highest court of judicial appeal and the second branch of the legislature. These dual functions stemmed from Parliament's original role as a court of law, although the Lords dropped their original jurisdiction during the reign of Charles II and thereafter concentrated exclusively upon appeals. ${ }^{16}$

The English colonial councils provided an additional precedent for the intermingling of the judiciary with the powers of other

(MacMillan, 1971). See also Oliver Morton Dickerson, American Colonial Government: 1696-1765 (Russell \& Russell, 1962). For a detailed summary of matters reviewed by the Privy Council during the colonial period, see Elmer Beecher Russell, The Review of American Colonial Legislation by the King in Council (Octagon, 1976).

${ }_{13}$ Goebel, 1 History of the Supreme Court at 69 (cited in note 12).

14 John P. Frank, Historical Bases of the Federal Judicial System, 13 Law \& Contemp Problems 3, 5 (1948). For a discussion of specific colonial statutes invalidated by the Council's exercise of legislative or judicial review, see Joseph Henry Smith, Appeals to the Privy Council from the American Plantations 531-551 (Columbia, 1950).

1s Holdsworth, A History of English Law at 397 (cited in note 3).

${ }^{16}$ For a discussion of the historical role played by the House of Lords in both the legislative and judicial systems of England, see George Burton Adams, Constitutional History of England (Henry Holt, 1934). 
branches. Modeled on the Privy Council, the colonial councils possessed executive, legislative, and judicial powers. Although the governor dominated colonial administration, the council sat as the upper house of the legislature and the court of appeals, and also consulted with the governor on executive decisions. ${ }^{17}$ Actions of the colonial councils were ultimately subject to review by the Privy Council. The councils consisted of twelve members appointed by the King upon recommendation of the Governor. ${ }^{18}$ Although the members of the colonial councils tended to be local dignitaries rather than judges, the councils exemplify England's relaxed attitude toward distinct branches, such as the judiciary, possessing overlapping powers.

Despite these historical practices, a strong but rather idealistic notion of judicial independence also existed in England around the time of the Constitutional Convention. Structurally, this judicial independence was reflected in the growing trend towards establishing set tenures and steady sources of revenue for judges. ${ }^{19}$ Yet a grander principle, perhaps best exemplified centuries earlier by Sir Edward Coke, lay at the heart of the notion of judicial independence. In Dr. Bonham's Case, Coke asserted that the judiciary was duty bound to strike down legislation contrary to the judge-created common law. ${ }^{20} \mathrm{He}$ maintained that the law was superior to the will of the sovereign. It followed that it would require an independent

17 See also Leonard Woods Labaree, Royal Government in America: A Study of the British Colonial System Before 1783 134-71 (Yale, 1930).

18 Id at 135.

19 See Paul R. Verkuil, Separation of Powers The Rule of Law and the Idea of Independence, 30 Wm. \& Mary L. Rev. 301, 305, 322 (1989). See also Shimon Shetreet, Judicial Independence: New Conceptual Dimensions and Contemporary Challenges, in Shimon Shetreet \& Jules Deschenes, Judicial Independence: The Contemporary Debate 590, 601-02 (Martinus Nijoff, 1985).

${ }^{20} \mathrm{Dr}$. Bonham's Case, 8 Coke Reports 116, 121 (1610). For a thorough discussion of Coke's commitment to judicial independence, see Catherine Drinker Bowen, The Lion and the Throne: The Life and Times of Sir Edward Coke (1552-1634) 291-317 (Little Brown, 1957). For a critical discussion of the English tradition of judicial independence, see Martin Shapiro, Judicial Independence: The English Experience, 55 NC L Rev 577 (1977). Shapiro argues that:

Insistence on judicial independence as an essential element in the conventional prototype of courts is largely derived from English experience. But it is largely derived from rather casual impressions of what the English courts appeared to be like in the eighteenth and nineteenth century. When the entire history of English judicial experience is reviewed, a far less clear picture of judicial independence emerges.

Id at 651 .

Although some delegates to the Federal Convention came to similar conclusions, most possessed an almost religious faith that the English system was the exemplar of judicial independence. See Verkuil, $30 \mathrm{Wm}$. \& Mary L. Rev. at 322 (cited in note 19); Shetreet, Judicial Independence at 601 (cited in note 19). 
judiciary, uninfluenced by the legislature or executive, to expound this law. Yet, despite this vague notion of judicial independence, true independence of the judiciary from the other branches, an idea which members of the Convention would later invoke in criticizing the idea of a Council of Revision, was not readily apparent in English practices.

\section{B. Philosophical Precedents}

At the time of the Convention, the Framers faced two competing models on which to structure the judiciary: one in which the judiciary played a significant role in the formation of laws and another in which the judiciary remained independent of the functions of the other branches. These models were not only the product of historical experience, but also of political philosophy in vogue at the time of the founding. In developing their separation of powers theory, a number of Framers relied on Montesquieu's Spirit of the Laws. ${ }^{21}$ Montesquieu believed that deliberate inefficiencies, in the form of checks and balances among the three branches, formed the basis of free government. Centralized power bred tyranny; to ensure freedom, the three branches of government had to be kept separate and in constant competition. Montesquieu supported this theory with a description of the English government that depicted three independent, competing branches, particularly an independent judiciary ${ }^{22}$ Although Montesquieu in reality espoused a fairly pragmatic concept of the separation of powers, he was widely interpreted in America as standing for the theory of completely separate governmental branches. ${ }^{23}$ As will become evident, a number of

21 Montesquieu, The Spirit of the Laws, Book XI, ch 6 (Hafner Press, trans Thomas Nugent, 1949). Montesquieu's views on the separation of powers were explicitly invoked by several delegates. See the remarks of Butler, Max Farrand, ed, 1 The Records of the Federal Convention of 1787391 (Yale, 1911)("Farrand") and remarks of Madison, 2 Farrand at 34. Yet note also that Montisquieu's views were implicit in many of the arguments made over separation of powers issues.

${ }_{22}$ Montesquieu, Spirit of the Laws, Book XI, ch 6 (cited in note 21). See also Forrest McDonald, Novus Ordo Seclorum: The Intellectual Origins of the Constitution 81-85 (U Kansas, 1985) and Federalist 47 (Madison) in Clinton Rossiter, ed, The Federalist Papers 300 (Mentor, 1961), in which Madison discusses Montesquieu and the separation of powers. Regarding the role of the judiciary in the separation of powers, Thomas Pangle has argued that, for Montesquieu, "[t]he separation of judicial powers is the most important part of the separation of powers ...." Thomas L. Pangle, Montesquieu's Philosophy of Liberalism 13233 (U of Chi, 1973).

2s For an incisive discussion of the pervasive misinterpretation and manipulation of Montesquieu's theories in support of a radically separate separation of powers system, see Gordon S. Wood, The Creation of the American Republic 1776-1787 152-54, 449-53 (U NC, 1964). See particularly the section discussing the effect of this "enhanced definition" of the 
Framers relied on this skewed interpretation of Montesquieu in the debates over the Council of Revision.

Other Framers were less dogmatic. They followed William Blackstone's observation that a government ultimately has one source of power-in England, the King; in the United States, the people. ${ }^{24}$ Under Blackstone's reasoning, the three branches of the English government, while technically separate, are really "thoroughly interwoven;" their separation was merely a matter of practical expediency. ${ }^{25} \mathrm{~A}$ flexible separation of powers, rather than an absolute one, permitted liberty to flourish by checking the potential for centralization, while at the same time ensuring that government would not be paralyzed by isolated, warring branches. In sum, the theoretical dispute at the root of the Council of Revision debate is reflected in this observation by Forrest McDonald: "Where Blackstone saw one force consisting of three complementary and independent parts, ... . Montesquieu saw three separate and functionally distinct branches. . . ."26

This philosophical difference on the separation of powers was particularly evident in the debates over the Council of Revision. In those debates, it was Madison, often viewed as a strong adherent of Montesquieu's separation of powers scheme, who took a position akin to Blackstone's view. ${ }^{27}$ Other Framers, disregarding the 18th century English judiciary's heavy involvement in the functions of the other branches, rejected Blackstone's view of the separation of powers in favor of the more idealistic interpretation of Montesquieu.

The historical traditions and philosophical notions of the role of the judiciary provided the Framers with plausible models for either a Council of Revision or an independent judiciary. In their debates over the Council of Revision, the Framers knew of and relied upon England's historical precedents. The extensive involvement of the Privy Council and the colonial councils in colonial affairs made them familiar institutions to the Framers. At the Convention, Gouverneur Morris mentioned both the House of

separation of powers upon the judiciary. Id at 453-63. Note also that the jury was Montesquieu's ideal vehicle for exercising judicial power, though this was not the interpretation given his writings in America. See Pangle, Montesquieu's Philosophy of Liberalism at 132 133 (cited in note 22).

${ }^{24} \mathrm{Sir}$ William M. Blackstone, 1 Commentaries on the Laws of England 48-52 (Chicago, 1st ed facsimile, 1979).

${ }_{25}$ McDonald, Novus Ordo Seclorum at 210 (cited in note 22).

${ }^{26}$ Id at 212.

${ }^{27}$ See text at notes 73-74. 
Lords and the Privy Council as precedents for a Council of Revision. ${ }^{28}$ Similarly, James Madison invoked the example of the House of Lords to demonstrate that mixing the executive and judicial branches on the Council was an established practice. ${ }^{29}$ As for the competing political philosophies influencing debates over the Council, the Framers' familiarity with the theories of Blackstone and Montesquieu is well documented. ${ }^{30}$ When the Framers' debate over the Council of Revision is viewed in light of these precedents and theories, the underlying reasons for both sides' positions become clearer.

\section{The Council of Revision in New York State}

While English practices and contemporary political theory provided the general backdrop for the debates over the Council of Revision, a more tangible influence on the Framers was the New York Council of Revision. At the time of the Constitutional Convention, only two state constitutions provided a veto power over the legislature. The Massachusetts Constitution of 1780 granted a limited veto power to its Governor and the New York Constitution of 1777 vested the veto power in a Council of Revision. ${ }^{31}$ Other states' constitutions provided no structural check at all upon the lawmaking power of the legislature. ${ }^{32}$ The Framers thus had three state models of judicial involvement in the legislative process from which to choose: the Council of Revision, the executive veto, and no veto at all. Given the fear of legislative tyranny that pervaded the debates at the Federal Convention, instituting no check was an implausible alternative. ${ }^{33}$ Therefore, the Framers were faced with a choice between a Council of Revision, in which the judiciary played a direct role in lawmaking, and a presidential veto, in which it did not.

28 Farrand at 75 (cited in note 21 ).

291 Farrand at 139 (cited in note 21).

so See McDonald, Novus Ordo Seclorum 81-85 (cited in note 22).

s1 For the text of the New York Constitution of 1777, see Ben Penley Poore, 2 The Federal and State Constitutions, Colonial Charters, and Other Organic Laws of the United States 1328 (GPO, 2d ed 1878) ("Poore"). For the text of the Massachusetts Constitution of 1780, see 1 Poore at 956. Part 2, Chapter III, Article II of the Massachusetts Constitution provides that the governor or legislature could require the supreme court to give opinions on "important questions of law" and on "solemn occasions," but the judiciary was given no formal lawmaking power. Id at 968-69.

32 See, for example, the Delaware Constitution of 1776 in 1 Poore at 273-78 (cited in note 31 ).

ss See text accompanying notes 61-64, discussing the Framers' fear of legislative dominance in the federal government. 
The New York Council of Revision provided a blueprint for the proposed national Council of Revision. The Framers relied heavily on the New York Constitution's principle of a strong check on the legislature. Before the Federal Convention, James Madison, the chief architect of the proposed national Council of Revision, expressed his admiration of the New York Council. ${ }^{34}$ Writing in defense of the executive veto in Federalist 73, Alexander Hamilton noted the utility of the New York Council in the formation of laws. ${ }^{35}$ Given the influence of the New York Council on the minds of these prominent Framers, a knowledge of its structure and operation is essential to understanding the proposal made at the Federal Convention and the Framers' debates over that proposal.

The story of the New York Council of Revision reveals one of the most novel and ambitious experiments in the history of American governmental institutions. Soon after the colonies declared independence from England in 1776, New York adopted its first constitution. According to Gordon Wood, the framers of this constitution were "[t]orn in two directions-between the inherited dread of magisterial despotism and a fear of popular disorder which was greater than that of any state at the time. . ." ${ }^{\prime 36}$ To avoid these two extremes, they chose a middle road by creating a Council of Revision, which checked the popular will of the legislature while refusing to place the power to check that will in a single person. Section III of the New York Constitution of 1777 established the Council:

And whereas laws inconsistent with the spirit of this constitution, or with the public good, may be hastily passed: Be it ordained that the governor for the time being, the chancellor, and the judges of the supreme court, or any two of them, together with the governor, shall be and hereby are, constituted

34 See, for example, Madison's letter to Caleb Wallace, dated August 23, 1785, concerning a potential constitution for Kentucky. Madison wrote that:

As a further security against fluctuating \& indegested laws the Constitution of New

York has provided a Council of Revision. I approve of such an institution \& believe it is considered by most intelligent citizens of that state as a valuable safeguard both to public interests \& private rights.

Robert A. Rutland, et al, eds, 8 The Papers of James Madison 350-51 (Chicago, 1973). See also Madison's comments on Jefferson's decision to include a Council of Revision in his draft of a constitution for the state of Virginia. 11 Papers of James Madison 292-93.

${ }^{35}$ Federalist 73 (Hamilton) in The Federalist Papers at 441, 446 (cited in note 22). It should be noted, however, that Hamilton's praise of the New York Council may have been influenced by his desire to persuade the people of New York to ratify the federal Constitution.

${ }^{36}$ Wood, The Creation of the American Republic at 433 (cited in note 23). 
as a council to revise all bills to be passed into laws by the legislature. . . .37

The language of this provision closely resembles that of the provision for a proposed federal Council of Revision. ${ }^{38}$ The contours of the Framers' idea for a federal Council of Revision become even clearer when one considers the actual operation of the New York Council.

The basic structure of the New York Council was straightforward. Membership consisted of the Governor, the state Chancellor (the chief judicial officer in the equity branch), and the Justices of the Supreme Court, or any two of them acting together with the Governor. The legislature presented all bills to the Council. The Council reviewed the bills and could veto any of them by a majority vote of its members. The legislature could override a veto by a two-thirds vote in both legislative houses. ${ }^{39}$

The primary purpose of the Council was to revise legislation. Thus, if the Council objected to any measure of a bill, it would return a detailed list of its objections to the legislature. ${ }^{40}$ The legislature could change the bill to conform to those objections, override the objections, or simply let the bill die..11 During its existence, the Council returned 169 bills to the legislature with objections. ${ }^{42}$ The legislature overrode 51 of these vetoes and reenacted at least 26 bills with various degrees of modification. ${ }^{43}$ This activity reveals the substantial role that the Council played in the early lawmaking process of New York.

The New York Council of Revision could veto legislation on virtually any grounds. Between 1777 and 1787, the objections raised by the Council in its veto messages ranged from an act being "inconsistent with the spirit of the Constitution"44 to an act being passed without "the persons affected thereby hav[ing] an opportunity of being heard."45 Although most of the Council's veto

372 Poore at 1332 (cited in note 31 ).

s8 See 1 Farrand at 21 (cited in note 21). The relevant language of the federal proposal is quoted in the text accompanying note 59 .

39 Id.

102 Poore at 1332 (cited in note 31 ).

11 Id.

12 Frank M. Prescott and Joseph F. Zimmerman, The Council of Revision and the Veto of Legislation in New York State: 1777-1821 2 (SUNY Albany, Graduate School of Public Affairs, 1972) ("Council of Revision").

43 Id at 5.

1 Alfred Billings Street, The Council of Revision of the State of New York 212 (William Gould, 1859).

${ }^{45}$ Id at 245. For a selection of the veto messages delivered by the Council, see id at 201- 
messages spelled out the detailed grounds for rejection and thus resembled judicial opinions, others looked more like bald policy pronouncements. In certain cases, for example, the Council vetoed bills simply because it considered them "inconsistent with the public good." a smallpox regulation bill on these grounds. ${ }^{47}$ Other messages were characterized by overt moral or political sermonizing. For example, in rejecting a bill that would have barred those convicted of adultery from ever marrying, the Council reasoned that:

It might not, perhaps, be an improper punishment to confine offenders of this class to a state of perpetual celibacy and mortification within the walls of a cloister, but to suffer them to remain in society without a possibility of remarrying is, in a degree, to compel them by law to live in the open violation of the rules of chastity and decency, ...48

Unpersuaded by the Council's reasoning, the legislature overrode the Council's objections.

The Council did not shrink from tough stands on controversial or politically charged issues; indeed, it played a major role in New York's early political struggles. Early in its existence, for example, the Council vetoed an act that stripped certain Loyalists of their citizenship and declared them aliens. Although a majority of New York legislators favored the act, the Council did not hesitate to reject it on seven different grounds, the first of which was that it "contradict[ed] the fundamental laws of every civilized nation." The Senate failed to override this veto. These examples of the Council's vetoes illustrate both the breadth of its activity and the range of reasons it could invoke to reject a bill.

One commentator has remarked that the members of the Council "framed [veto messages] with great care, and they consequently will be found marked by vigor, clearness and logical preci-

402. Prescott and Zimmerman calculate that " 55.6 per cent of the Council's objections were mainly for policy reasons, 21.8 per cent were for lack of constitutionality, and 12.4 per cent were disallowed because they were deemed both 'inconsistent with the spirit of the Constitution and with the public good' and other reasons of lesser significance." Prescott and Zimmerman, Council of Revision at 43 (cited in note 42).

18 Id at 258. See also Nathaniel H. Carter and William L. Stone, rptrs, Reports of the Proceedings and Debates of the Convention of 182155 (E. and E. Hosford, 1821) (remarks of Judge Jonas Platt, claiming that 44 vetoes were based solely on this ground). 44).

47 Street, The Council of Revision of the State of New York at 258-59 (cited in note

48 Id at 282.

19 Id at 246 . 
sion, both in thought and expression." of the Council's vetoes reflected attention to legal detail or constitutional concerns, others were squarely predicated on blatantly political considerations. Indeed, the Council conceived of itself as a potent political force. As Julius Goebel observed, "[ $t]$ he records of the Council, especially in its early years of existence, demonstrate that the membership conceived that it possessed a broad mandate." $" 151$

The New York Council gradually ran into problems as it became mired in a power struggle with the legislature and as it came to be perceived as an obsolete and dangerously undemocratic institution in an increasingly populist age. In 1821, after it deliberately thwarted the Assembly's call for a constitutional convention, the Council was bitterly reproached in the New York Assembly. The Assembly had wanted to revise the state Constitution in order to overhaul the Council of Appointment, a body responsible for appointments to government positions, which had deteriorated into a sty of corrupt patronage. ${ }^{.2}$ To do so, the Assembly passed a resolution calling for a constitutional convention with general, rather than limited, authority to change the constitution. The Council, in a message written by Chancellor James Kent, vetoed the proposal. ${ }^{53}$ The Assembly overrode the Council's veto and lambasted the Council for usurping the legislature's role as the democratic representative of the people. ${ }^{54}$ Then came the convention.

At the convention, the Council of Revision itself became a major issue. Opponents of the Council argued that it had "usurped the power of judging the expediency as well as the constitutionality of bills passed by the legislature"s5 and that it should therefore be abolished and replaced with a purely executive veto. The President of the Convention claimed that "[t]he council had . . . in fact become a third branch of the legislature. . . ." Other delegates contended that New York should follow the example of the na-

so Id at 199.

${ }^{81}$ Goebel, 1 History of the Supreme Court at 104 (cited in note 12).

s2 Charles Z. Lincoln, 1 The Constitutional History of New York 620-26 (Lawyers Cooperative, Rochester, 1906).

ss Id at 624-25.

st Id at 626.

ss Carter and Stone, Reports of the Proceedings at 55 (cited in note 46) (Remarks that Judge Jonas Platt attributed to delegate Peter R. Livingston, the principal drafter of the 1777 New York Constitution).

s6 Id at 79. Delegates also expressed their outrage at judicial involvement in "party strife" and an alleged deterioration in the public's confidence in the judiciary. See id at 71 (remarks of Martin Van Buren); id at 83 (remarks of Abraham Van Vechten). 
tional government by adopting an executive veto. ${ }^{57} \mathrm{~A}$ small band of judges, led by Chancellor Kent, defended the Council on the grounds that it had not usurped legislative power, but had instead fulfilled its constitutional function by preventing the passage of unwise and unconstitutional legislation. ${ }^{58}$ The judges' argument did not prevail. The new constitution of 1821 placed all veto power in the Governor and abolished the Council of Revision.

The New York Council initially fulfilled its purpose of providing a compromise between the monarchic attributes of an executive veto and the dangers of unrestrained legislative power. Particularly at the time of the Federal Convention, the New York Council was a popular, efficient, and respected institution of governance that the Framers might well have adopted without many reservations. However, over time, the workings of the New York Council revealed the inherent structural and political weaknesses of an institution that drew members of the judiciary into political battle and thereby threatened democratic decision making. Indeed, the events preceding the end of the New York Council indicate that a council or council-like structure on the federal level could have eventually posed a major threat to the democratic underpinnings of the national government.

\section{The Proposal, Debate, and Rejection of the Counch of Revision at the Federal Constitutional Convention}

Resolution 8 of the original Virginia Plan contained the proposal for a national Council of Revision. John Randolph officially submitted the proposal to the Convention on May 29, 1787. It read as follows:

Resd. that the Executive and a convenient number of the National Judiciary, ought to compose a council of revision with authority to examine every act of the National Legislature before it shall operate, \& every act of a particular Legislature before a Negative thereon shall be final; and that the dissent of said Council shall amount to a rejection, unless the act of the National Legislature be again passed, or that of a particular Legislature be again negatived by [ ] of the members of each branch. ${ }^{59}$

${ }^{87}$ Id at 47 (remarks of Peter A. Jay). The entire range of arguments for and against abolishing the Council is given in id at 44-121.

s8 Id at 87-88.

59 1 Farrand at 21 (cited in note 21). 
By its terms, this resolution proposed a body that would have the power to veto all federal laws passed by the Congress and either approve or reject congressional vetoes on state laws. ${ }^{60}$ The Framers debated this proposal, and a variation of it that would have presented bills separately to the President and to the judiciary, on June 4, June 6, July 21, and August 15 of 1787 . This section of the comment will examine the arguments for and against the Council in order to discern the basic substantive and structural principles that motivated the Framers' rejection of it.

\section{A. Arguments in Favor of the Council}

Supporters of the proposed Council advanced three main arguments in its favor. First, they argued that the Council of Revision provided a needed check on the legislature in the separation of powers system. James Madison and James Wilson argued that the President would need the judiciary's help to check the power of the legislature because an executive veto alone would not suffice. Wilson asserted that the executive and the judiciary could only "preserve their full importance against the legislature" by jointly exercising the veto power. ${ }^{61}$ Madison added that a Council, unlike a single, weak executive, would "render [the] Check or negative more respectable. ..." S2 Since the legislature would have "a powerful tendency ... to absorb all power into its vortex" the Constitution had to give "every defensive authority to the other departments" as long as such authority was "consistent with republican principles." $"$ 3

At the time of the Federal Convention, the widespread phenomenon of overbearing state legislatures supported Madison and Wilson's warning that the President alone would be an ineffective check against the Congress. ${ }^{64}$ The delegates to the Federal Convention, like those at the New York Convention of 1777, were justifia-

so Because the Convention rejected a congressional veto over state laws, this comment will not address the Council's review of such vetoes. The issue was not addressed in the debates over the Council.

o1 1 Farrand at 105 (cited in note 21).

62 Id at 108.

6s 2 Farrand at 74 (cited in note 21 ).

or A concise discussion of the Framers' fear of overly powerful legislatures at the time of the Convention can be found in Wood, Creation of the American Republic at 403-09 (cited in note 23). In his famous study of 19th century American government, Woodrow Wilson makes the argument that the whole first century of the American government was marked by congressional dominance and executive weakness. Woodrow Wilson, Congressional Government: A Study in American Politics (Houghten Mifflin, 1925). 
bly concerned about the potential for either executive or legislative tyranny. As in New York, the proposed Council of Revision offered a compromise between these two extremes by placing a weighty check upon the legislature while diluting the President's power by forcing him to act in concert with the judicial branch in exercising the veto.

A second argument for the Council of Revision posited that the use of the legal knowledge and skills of judges would improve the lawmaking process. Madison asserted that effective government required "collect[ing] the wisdom of its several parts in aid of each other whenever it was necessary." idea by stating that legal advice from members of the judiciary "would be useful to the Legislature by the valuable assistance it would give in preserving a consistency, conciseness, perspicuity \& technical propriety in the laws. . . ."66 According to Madison, good lawmaking required the input of judicial minds at the outset. Oliver Ellsworth offered a variation on this theme by pointing out that "[t]he law of Nations . . . will frequently come into question [in legislating]. Of this the Judges alone will have competent information." 67

Under the reasoning of Madison and Ellsworth, the fact that judges possessed unique skills and knowledge would enable the Council to produce "better" laws. This reasoning led to the argument that judges should be able to decide on the wisdom, or policy, of a law. James Wilson argued that without judicial participation in lawmaking,

[1]aws may be unjust, may be unwise, may be dangerous, may be destructive; and yet not be so unconstitutional as to justify the Judges in refusing to give them effect. Let them have a share in the Revisionary power, and they will have an opportunity of taking notice of these character[istics] of a law, and of counteracting, by the weight of their opinions the improper views of the Legislature. ${ }^{68}$

As this passage shows, Wilson conceived of the judge's role as correcting the "improper views" of the elected representatives, rather than merely as a restrained and subordinate expositor with no role in substantive policy making. Similarly, George Mason warned

\footnotetext{
6s 1 Farrand at 110 (cited in note 21).

68 2 Farrand at 74 (cited in note 21).

67 Id at 73-74 (emphasis added).

${ }^{68}$ Id at 73.
} 
that if judges were limited only to inquiring as to the constitutionality of a law after the law had been passed, "every law however unjust[,] oppressive or pernicious, which did not come plainly under this description" would be given free course. ${ }^{69}$ Mason added to this conception by noting that judges would be particularly skillful in resisting unwise laws because "they are in the habit and practice of considering laws in their true principles, and in all their consequences." Mo Mason apparently assumed that judges' legal skills would help them to determine the wisdom as well as the constitutionality of a law. He made no mention, however, of what criteria, other than personal preference or legal soundness, the judges would have used to decide if a law were "unjust" or "oppressive," or of what factors would constrain this decision. To delegates such as Wilson and Mason, judges were the ultimate guardians of the polity.

The New York Council demonstrated the feasibility of the idea of a national Council because it presented a concrete example of judges making substantive public-policy decisions and playing an important role in the separation of powers system of New York. The wide range of reasons that the members of the New York Council could invoke to revise a bill squared neatly with the broad powers that Mason contemplated for judges sitting on a national Council of Revision. Moreover, the New York Council functioned as a check upon the legislature in much the same way that delegates such as Madison and Wilson contemplated the national Council would function as a check upon Congress. In other words, the New York Council was the embodiment of the Council of Revision envisioned by Madison, Wilson and other proponents of the proposal for a federal Council.

In championing the Council, however, delegates such as Madison seem to have overlooked the danger that a policy making role for the judiciary, while appearing a practical and expeditious way of resolving the legal issues that plague legislation, could seriously impinge upon the more fundamental policy of popular sovereignty. Under that principle, "good" lawmaking was not a function of legal skill, but of the will of the people. A Council of Revision would have taken advantage of the legal skills that the judiciary could bring to lawmaking, thereby fulfilling Madison's broader goal of each branch aiding the others where such aid was possible. However, this could only be achieved at the cost of giving unelected 
officials the power to make policy which would, in turn, undercut the notions of popular sovereignty that animated the whole Convention. As will be seen, this concern played a significant part in the defeat of the proposed Council.

A third argument in favor of the Council of Revision sought to counter the claims that a Council would radically depart from the sacrosanct principle of "judicial independence." Proponents of the Council pointed to the strong English precedent of mingling the judiciary in the exercise of non-judicial powers, and argued that this practice should be followed by the federal government, as it had been in New York. Drawing upon the historical precedents examined earlier, Gouverneur Morris asserted that:

The truth was that the Judges in England had a great share in ye Legislation. They are consulted in difficult \& doubtful cases. They may be $\&$ some of them are members of the Legislature. They are or may be members of the privy Council, and can there advise the Executive as they will do with us if the motion succeeds. ${ }^{71}$

In response, opponents of the Council asserted that the general principle of "judicial independence" was inviolate and essential to a strict separation of powers system, despite contrary practices in England. ${ }^{72}$

Ultimately, this dispute was between a rigid and a flexible theory of the separation of powers. Madison, a pragmatist when it came to the separation of powers, reminded the delegates that, "the Executive [in England] had an absolute negative on the laws; and the supreme tribunal of Justice (the House of Lords) formed one of the other branches of the Legislature." ${ }^{\text {"3 }}$ Using these English practices as examples, Madison argued that one could not realistically establish a government upon an overly doctrinaire interpretation of political philosophy; some accommodations to practicality had to be made. The separation of powers could only work in practice by combining the branches where the system required such combinations for its efficient operation. To "guarantee the provisions on paper," the separation of powers had to be flexible and accommodate some overlap between the branches. ${ }^{74}$ Although

11 Id at 75.

72 See text accompanying notes 76-81.

${ }^{23} 1$ Farrand at 139 (cited in note 21).

742 Farrand at 77 (cited in note 21). See also id at 78 (Gouverneur Morris states that the Council would be a "defensive provision for securing the effectual separation of the departments ....") (emphasis added); Federalists 47 and 51 (Madison) in The Federalist 
this argument prevailed in other contexts at the Convention, ${ }^{75}$ it failed to convince the delegates that they should go so far as to seat judges on a Council of Revision. The rejection of the Council of Revision represented one of the rare triumphs enjoyed by the proponents of a more radical separation of powers.

In the end, the case in favor of the Council of Revision came down to three points: the need for a Council to operate as a check against the legislature, the need for the skill and wisdom of judges in lawmaking, and the historical practices in the English government that supported a flexible separation of powers. All three arguments had impressive historical and logical foundations and were put forth by strong advocates. Yet these considerations failed to tip the balance when weighed against the arguments raised by those who opposed the Council.

\section{B. Arguments Against the Council of Revision}

Those delegates who opposed the Council of Revision held a fundamentally different conception of the role of the judiciary in the separation of powers system and the role of judges in the lawmaking process from those in favor of the Council. The opponents of the Council, driven by the ideal of a radically independent judiciary, rejected the notion that the judicial branch should be used as a check on the legislature, except by its exercise of judicial review. In addition, they rejected the notion of policy making judges on the grounds of democratic accountability and popular sovereignty. Finally, the Framers who voted to reject the Council were concerned about the potential for biased judging and about the sullied reputation of the courts should they become political institutions.

Opponents of the Council of Revision argued that the Council would threaten the delicate separation of powers system that the Framers were trying to create. John Dickinson argued that placing members of the judiciary on a Council of Revision would create "an improper mixture of powers," which would skew the proper functioning of the separation of powers system. ${ }^{76}$ Elbridge Gerry shared this sentiment. ${ }^{77} \mathrm{He}$ and other opponents insisted that such skewing would produce sinister results. Gerry claimed it would fos-

\footnotetext{
Papers at 300,320 (cited in note 22).

${ }^{75}$ For example, the executive veto (US Const, Art I, \& 7, cl 2), the shared appointment power (Art II, § 2, cl 2), and the impeachment provisions (Art I, § 2, cl 5 and $\S 3, \mathrm{cl} 6$ ).

761 Farrand at 140 (cited in note 21).

77 Id at 139.
} 
ter "an improper coalition between the Executive \& Judiciary departments" that would prostrate Congress and lead to tyranny. ${ }^{78}$ Nathaniel Gorham asserted that it would lead to judicial dominance of the executive. ${ }^{7 \theta}$ These Framers were particularly concerned that a Council that possessed a substantial share of the legislative power would tread too heavily upon the powers of Congress and would dilute the power of the President.

The supporters of the Council attacked the position that combining the judiciary and the executive on the Council would endanger the separation of powers scheme. As discussed above, they felt that the Council should play an integral role in checking the excesses of legislative power. Madison argued that if a judicial share in the veto power violated the principle of a strict separation of powers, then, by the same logic, so did a single executive's use of the veto power. ${ }^{80}$ Yet it was not hard for opponents of the Council to distinguish the notion of an "independent" executive from that of an "independent" judiciary. The judiciary, unlike the legislature and the executive, was not selected democratically. Moreover, in his writings Montesquieu particularly emphasized the need to keep the "terrible" judicial power isolated. . $^{81}$

In a vein similar to Madison's, James Wilson labored to make a distinction between lateral powers, like commanding the military, which could only be vested in one branch, and collateral powers, like revising the laws, which could be vested in more than one branch. ${ }^{82}$ Yet this strained distinction did not persuade those who held to a strict notion of the separation of powers since it implied that the judiciary was not an independent power, but just another political branch. Political matters, however, were to be decided only by representatives of the people-Congress and the President. Such matters could not simply be assigned to the unelected members of the judiciary, even as an additional structural check, without seriously jeopardizing considerations of popular sovereignty.

Several opponents of the Council argued that a combination of the executive veto and judicial review would provide sufficient means to control a rambunctious Congress and that a Council was therefore unnecessary. Elbridge Gerry, for example, argued that placing the veto in the hands of the President would itself suffice

\footnotetext{
782 Farrand at 75 (cited in note 21).

79 Id at 79.

so Id at 77.

81 Montesquieu, Spirit of the Laws at 153 (cited in note 22).

82 I Farrand at 140: 2 Farrand at 78 (cited in note 21).
} 
as a direct check against legislative excess. ${ }^{83}$ Furthermore, the Supreme Court's power of judicial review would provide "a sufficient check agst. [legislative] encroachments. . . ."84 Taking judicial review as a given, Luther Martin opposed the idea of including judges in the revisionary power because it would give them a "double negative" over the laws when joined with the power of judicial review. ${ }^{85}$ Under such reasoning, the Council's role as a check would be not only dangerous, but superfluous.

A second argument raised by opponents of the Council of Revision was that judges, by definition, should not decide matters of public policy. Elbridge Gerry claimed that "[i]t was quite foreign from the nature of [the judicial] office to make them judges of the policy of public measures." ${ }^{\text {"86 }}$ Similarly, Caleb Strong stated that "[n]o maxim was better established" than that "the power of making ought to be kept distinct from that of expounding, the laws." These statements, however, beg the deeper question of why the opponents of the Council felt that judges should not decide matters of public policy as a Council of Revision.

The Framers generally believed that judicial power should be used to resolve private disputes between particular parties, not matters affecting the general public. ${ }^{88}$ The opposition to judges as policy makers was predicated upon the notion that judges should only exercise this limited, inherent "judicial" power, not "executive" or "legislative" powers. This conception of a limited judicial role stemmed from concerns of democratic accountability. Keeping the power to make laws in the hands of elected representatives assured such accountability. The ideal of popular sovereignty that undergirds the entire Constitution requires that matters of general public concern ultimately be decided by the people through their electorally accountable representatives. "[A] knowledge of mankind, and of Legislative affairs [could] not be presumed to belong to a higher degree to the judges than to the Legislature" because unlike legislators, judges did not represent the people. ${ }^{89}$ Only those

83 1 Farrand at $97-98$ (cited in note 21 ).

si Id at 97 (Gerry).

ss 2 Farrand at 76 (cited in note 21 ).

so Id, I Farrand at 97-98 (cited in note 21).

s2 2 Farrand at 75.

s8 See Madison's discussion of "private rights" and "public good" in Federalist 10 in The Federalist Papers at 53 (cited in note 22). See also, Walter Berns, Taking the Constitution Seriously 202-06 (Simon and Schuster, 1987).

s9 2 Farrand at 76 (cited in note 21) (remarks of Luther Martin). See also id at 73 (remarks of Gorham). 
who had faced the electorate were presumed to have "knowledge" of legislative or public policy matters. To place unelected judges in a policy making role on a Council of Revision would be perverse; it would, according to Gerry, "mak[e] the Expositors of the Laws, the Legislators which ought never to be done."90

Opponents of the Council next argued that placing judges in a lawmaking role would bias the judges by involving them in both the creation and the review of particular laws. Nathaniel Gorham stated that "[J]udges ought to carry into the exposition of the laws no prepossessions with regard to them."91 Similarly, Charles Pinckney worried that placing judges on the Council would "give a previous tincture to their opinions." the potential for judicial "prepossessions" as a major theoretical flaw in the structure of the Council, even though this problem would not often arise in practice. The judges on the New York Council of Revision, for example, only reviewed as a Court a very small percentage of the laws that it struck down and the legislature overrode..$^{93}$ Moreover, when the Justices did review one of these laws in the context of a case, the law would be enmeshed in a particular set of facts. This would limit the degree to which judges could act on their policy biases. Understanding this, Madison argued that only a small fraction of the bills reviewed by the Council would be "so ambiguous as to leave room for [a judge's] prepossessions. . .."94 Yet opponents of the Council apparently reasoned that even the potential for this sort of structural bias was too great to risk involving the judiciary in a dual role.

Finally, the Council's opponents worried that placing judges on a Council of Revision would erode public confidence in the judiciary, since it would cast the judges as players in the rough world of partisan politics. Luther Martin, for example, claimed that confidence "will soon be lost, if [judges] are employed in the task of remonstrating agst. popular measures of the Legislature."95 The downfall of the New York Council and the demise of the powerful English Privy Council of the early seventeenth century were attributable in large part to the involvement of judges in partisan politics and the corresponding decline of public confidence in an im-

\footnotetext{
so Id at 75.

91 Id at 79 .

${ }^{92}$ Id at 298.

${ }^{93}$ Prescott and Zimmerman, Council of Revision at 43 (cited in note 42).

84 1 Farrand at 138 (cited in note 21).

95 2 Farrand at 77.
} 
partial judiciary. In England, the political involvement of the judiciary helped kindle the Civil War; in New York it led to a major constitutional crisis and subsequent constitutional revision.

On June 6, 1787, the Federal Convention rejected the proposed Council of Revision, as described in the Virginia Plan, by a vote of eight to three. ${ }^{96}$ On July 21 , the Convention voted down the same proposal upon reconsideration, four to three (with two delegations divided). ${ }^{97}$ On August 15, Madison made a last ditch effort to involve the judiciary in the lawmaking process by submitting a proposal that bills be presented separately to the executive and to the judiciary for review. The Convention soundly rejected this final proposal by a vote of eight to three. ${ }^{88}$

\section{The Historical Significance of the Framers' Rejection of THE CouncIl of Revision}

Current debate over a variety of controversial political and legal issues continues to raise questions concerning the role of the judiciary that the Framers discussed and decided upon in the debates over the Council of Revision. The history of the Council of Revision has often been used in analyzing these issues. Raoul Berger, for example, has relied on the Framers' rejection of the Council of Revision to support his argument for a narrow interpretation of the Fourteenth Amendment.99 Berger viewed the rejection of the Council as "the most significant single piece of evidence that the Framers excluded the judiciary from policymaking. . . ."100 Several Supreme Court Justices have invoked the Council in controversial cases. In Griswold $v$ Connecticut, Justice Black relied on the rejection of the Council to support his argument that the promulgation of vague, malleable standards in Fourteenth Amendment cases is "an attribute of the power to make laws, not of the power to interpret them."101 And in Board of Education $v$ Barnette, a First

281 Farrand at 140 (cited in note 21).

972 Farrand at 80.

${ }^{98}$ Id at 298.

90 Raoul Berger, Government by Judiciary: The Transformation of the Fourteenth Amendment 300-06 (Harvard, 1977).

${ }_{100}$ Id at 300 .

${ }^{201} 381$ US 479, 513 n 6 (1965) (Black dissenting). For similar treatment of the history of the Council of Revision in Fourteenth Amendment cases, see Goldberg $v$ Kelly, 397 US 254, 273 (1970) (Black dissenting) (courts were to have "no part whatever in making any laws," citing the rejection of the Council of Revision in support); Saia v New York, 334 US 558, 571 (1948) (Jackson dissenting) (in discussing a law challenged as an excessive grant of discretion to a police chief, Jackson stated that he "did not suppose our function was that of a council of revision."); Lewis v City of New Orleans, 415 US 130, 140 (1974) (Blackmun 
Amendment case, Justice Frankfurter referred to the Council of Revision in an effort to bolster his dissenting argument that the Court lacked the power to exercise "supervision over legislation."102

Others have invoked the Council of Revision in discussing the doctrine of standing, an issue that raises similar questions about the role of the judiciary in the lawmaking process. For example, Justice Powell offered an elaborate analogy between the Council of Revision and the potential effects of a liberalized standing law:

Unrestrained standing in federal taxpayer or citizen suits would create a remarkably illogical system of judicial supervision of the coordinate branches of the Federal Government. Randolph's proposed Council of Revision, which was repeatedly rejected by the Framers, at least had the virtue of being systematic; every law passed by the legislature automatically would have been previewed by the Judiciary before the law could take effect. On the other hand ... the allowance of public actions would produce uneven and sporadic review, the quality of which would be influenced by the resources and skill of the particular plaintiff. And issues would be presented in abstract form, contrary to the Court's recognition that 'judicial review is effective largely because it is not available simply at the behest of a partisan faction, but is exercised only to remedy a particular, concrete injury.'103

On the other hand, Professor Gene Nichol has argued that the role of the courts under a liberal standing regime cannot be compared to the role of the Council of Revision for three reasons: the Council was part of the enacting process itself rather than post-enactment review; review by the Council was directed at the wisdom of the bill, not merely its constitutionality; and, though the Framers rejected the Council, the Framers never doubted the existence of judicial review. ${ }^{104} \mathrm{He}$ therefore believes that such comparisons should die a "quiet death."

dissenting) (the Supreme Court's use of overbreadth and vagueness doctrines to invalidate legislation can "usurp the prerogative of democratic government," making the Court a "council of revision"); Trimble v Gordon, 430 US 762, 778 (1976) (Rehnquist dissenting) ("The Civil War Amendments did not make this court into a council of revision"). 102319 US 624, 649-650 (1943) (Frankfurter dissenting).

103 United States v Richardson, 418 US 166, 189-91 (1974) (Powell concurring) (citation omitted).

${ }^{104}$ Gene R. Nichol, Jr., Rethinking Standing, 72 Cal L Rev 68, 93-94 (1984).

${ }^{105}$ Id at 94. 
Two recent constitutional controversies also touch on two of the primary concerns raised in the debates over the Council. In Morrison v Olson, ${ }^{106}$ the Supreme Court confronted the issue of whether the judicial appointment of a special prosecutor was constitutional, deciding ultimately that the separation of powers was not endangered by such an arrangement. In upholding judicial participation in the Federal Sentencing Commission in Mistretta $v$ United States, the Supreme Court was forced to confront questions regarding the role of judges in deciding matters of substantive public policy as well as perceptions of judicial independence. ${ }^{107}$

While the history of the Council of Revision cannot, of course, conclusively dispose of these issues, it can reveal the broad structural and substantive principles that the Framers furthered in rejecting the Council and can serve as a guide to discovering both the proper operation of the separation of powers system and the role of judges and the judiciary in that system. These principles are relevant to analyzing current issues not simply because they evince the Framer's intentions, but more importantly because they are crucial to preserving the functioning of our constitutional system.

In searching for the policies underlying the rejection of the Council of Revision, one should bear in mind that the Framers were presented with and rejected a concrete model of direct judicial involvement in the lawmaking process. The Council of Revision proposal had an impressive pedigree in English and colonial institutions and a blueprint for its construction in the New York constitution. It was not lightly considered. The Framers knew how such an institution would function in practice and deliberately rejected it because that function did not conform to the structural and policy choices the Framers incorporated in the rest of the Constitution. The rejection of the Council was one of the crucial decisions made at the Convention. It exemplified the Framers' decision to repudiate generally accepted notions of the judicial role in favor of a radically different conception of that role.

On a structural level, the Framers' rejection of the Council demonstrated their adherence to a rigid, rather than a flexible, separation of powers system with regard to the role of the judiciary. Despite the strong arguments of Madison and Wilson in favor of a more flexible system, and despite the Framers' willingness to permit such flexibility in other areas, the opponents of the Council decided that they could not countenance a deviation from the role 
given to the judiciary in Montesquieu's strict, albeit exaggerated, theoretical model of the separation of powers. They concluded that such a deviation would have harmed the delicate balance of power within the national government.

Yet the importance of this balance is found in the principles that underlie it. On a policy level, the debates show that the Framers sought to balance the need for a check on Congress against the dangers of giving the unelected judiciary power to make policy. The Framers clearly recognized the need for a check on the legislature: they premised their rejection of the Council upon the condition that the Courts would have the power of judicial review. This condition qualifies the Framers' determination that a Council of Revision was not necessary to the effective functioning of the separation of powers system. The Framers intended to involve the courts as a check in the separation of powers system, but not in as direct a manner as a Council of Revision with an integral role in the lawmaking process would have allowed. Rather, the Framers intended the courts to function as an indirect check on the President and Congress through judicial review.

The Framers rejected the direct check that the Council would have provided because of the dangers of involving judges in the lawmaking process. Even though the advantages of such a practice were presented to them, the delegates decided that the qualitative improvement in legislating that judicial involvement would arguably bring was outweighed by three goals: popular sovereignty, electoral accountability, and judicial neutrality. The history of the New York Council of Revision reveals the wisdom of this judgment. Although the New York Council proved to be an acceptable institution in the early years, it increasingly blocked the surge of popular government and created significant political turmoil. The rejection of a national Council of Revision not only evinced distrust of judges in a lawmaking role and desire to keep them out of political debate, but also affirmed that democratic representation should pervade all of public policy making.

The Framers heartily disputed all of these matters, but in the end, they based their decision to reject the Council not upon its novelty or its technical impracticalities, but upon fundamental principles of governance. These principles have not been rendered obsolete by time. Indeed, they remain crucial to preserving the design of government created in 1787.

\section{ConCLUSION}

The Council of Revision is often invoked as a rhetorical 
weapon to argue for a more restrained role for the courts. Yet the history of the Council of Revision has more significance than merely lending rhetorical luster to vigorous dissents or strident articles. As this comment has shown, the Framers seriously considered the Council of Revision and their rejection of it reflected firm decisions about fundamental principles of the constitutional order. The Council was not, as it has sometimes been treated, an implausible or radical idea. Rather, the Framers rejected it because the legitimate policies for which it stood did not outweigh the arguments that were marshalled against it.

In retrospect, the saga of the New York Council of Revision suggests that the Framers were right. While the New York Council of Revision initially fulfilled its task of providing a compromise between legislative and executive dominance, it became, over time, an obsolete remnant of the tradition of using judges in the lawmaking process. It also posed a substantial threat to the growing democratic principles that held that the only legitimate form of legislating was with the consent of the governed. Courts and commentators should take heed of the historical relevance that can be gleaned from the Framers' decisions to reject the Council of Revision, to divorce the American judiciary from the long tradition of judicial intermingling and to sculpt for courts and judges a unique and limited role in the Constitutional scheme. 
